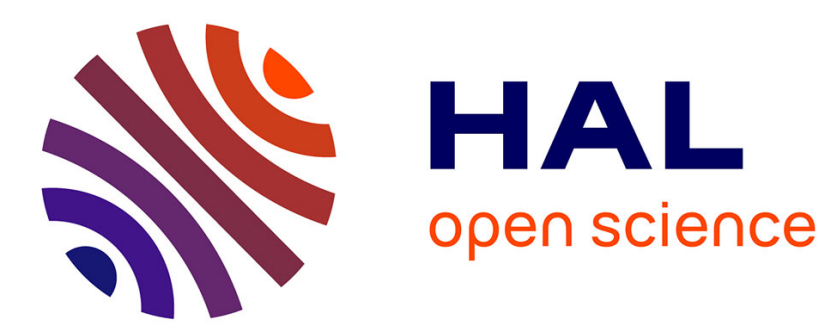

\title{
Decreased expression of the IGF-II gene during porcine adipose cell differentiation
}

Delphine Gardan, Jacques Mourot, Isabelle Louveau

\section{To cite this version:}

Delphine Gardan, Jacques Mourot, Isabelle Louveau. Decreased expression of the IGF-II gene during porcine adipose cell differentiation. Molecular and Cellular Endocrinology, 2008, 292 (1-2), pp.63. 10.1016/j.mce.2008.06.015 . hal-00532044

\section{HAL Id: hal-00532044 \\ https://hal.science/hal-00532044}

Submitted on 4 Nov 2010

HAL is a multi-disciplinary open access archive for the deposit and dissemination of scientific research documents, whether they are published or not. The documents may come from teaching and research institutions in France or abroad, or from public or private research centers.
L'archive ouverte pluridisciplinaire $\mathbf{H A L}$, est destinée au dépôt et à la diffusion de documents scientifiques de niveau recherche, publiés ou non, émanant des établissements d'enseignement et de recherche français ou étrangers, des laboratoires publics ou privés. 


\section{Accepted Manuscript}

Title: Decreased expression of the IGF-II gene during porcine adipose cell differentiation

Authors: Delphine Gardan, Jacques Mourot, Isabelle Louveau

PII: $\quad$ S0303-7207(08)00280-3

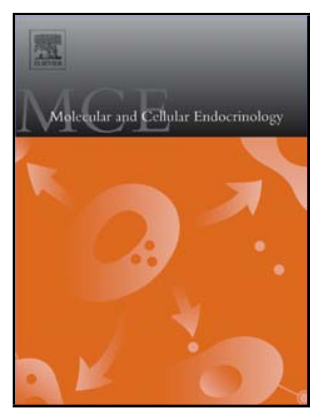

DOI: doi:10.1016/j.mce.2008.06.015

Reference: MCE 6909

To appear in: Molecular and Cellular Endocrinology

Received date: 19-3-2008

Revised date: 24-4-2008

Accepted date: 23-6-2008

Please cite this article as: Gardan, D., Mourot, J., Louveau, I., Decreased expression of the IGF-II gene during porcine adipose cell differentiation, Molecular and Cellular Endocrinology (2007), doi:10.1016/j.mce.2008.06.015

This is a PDF file of an unedited manuscript that has been accepted for publication. As a service to our customers we are providing this early version of the manuscript. The manuscript will undergo copyediting, typesetting, and review of the resulting proof before it is published in its final form. Please note that during the production process errors may be discovered which could affect the content, and all legal disclaimers that apply to the journal pertain. 
${ }^{1}$ INRA, UMR 1079, F-35000 Rennes, France

${ }^{2}$ Agrocampus Rennes, UMR1079, F-35000 Rennes, France

Address correspondence to: Isabelle Louveau, INRA, UMR 1079 SENAH, Domaine de la

Prise, 35590 St Gilles, France.

Tel: +3322348 5046

Fax: +33223485080

E-mail: Isabelle.Louveau@rennes.inra.fr 


\section{Abstract}

2 IGF-I and IGF-II are known to regulate cell development and recent data suggest a possible

3 role of IGF-II on adipose tissue development. This study was undertaken to examine the IGF

4

5 system gene expression in porcine differentiating adipocytes. Both adipocytes and stromalvascular (s/v) cells were isolated from subcutaneous adipose tissue collected from 7-day-old piglets. S/v cells were cultured in chemically defined medium. Compared with isolated adipocytes, IGF-II and IGFBP-5 mRNA levels were very high in freshly isolated s/v cells, whereas IGF-I mRNA levels were lower in s/v cells than in adipocytes. Between day 0 and day 6 of culture, IGF-II and IGFBP-5 gene expression decreased whereas expression levels of late markers of adipocyte differentiation were up-regulated. Cell differentiation was also associated with an increase in the expression of IGF-I, insulin and IGF receptor genes. The current findings suggest that IGF-I and IGF-II have different effects on porcine adipose cell development.

\section{Key words: IGF-I; IGF-II; IGFBP; preadipocyte; differentiation; pig}




\section{Introduction}

Insulin-like growth factor-II (IGF-II) is a single chain polypeptide that belongs to the family of insulin-related peptides, which includes also insulin and IGF-I (Jones and Clemmons, 1995; O’Dell and Day, 1998). IGFs interact with two types of cell surface receptors, type I and type II, that differ in their amino acid sequence, secondary structure and ligand-binding specificity; and they also interact with six high-affinity IGF binding proteins (IGFBP-1 to IGFBP-6 ; Jones and Clemmons, 1995 ; Firth and Baxter, 2002). These factors are potent growth regulators that exert biological effects in an endo-, para- and/or autocrine manner (Jones and Clemmons, 1995). Whereas IGF-II is known to play a key role in placental and fetal growth (Constância et al., 2002; Fowden, 2003), its action during postnatal life is much less documented (O’Dell and Day, 1998; Chao and D’Amore, 2008). An increasing number of studies argue for a possible role of IGF-II on adipose tissue development in mammals other than rodents.

Indirect evidence for effects of IGF-II on adipose tissue growth and development is provided by studies of igf2 gene polymorphism, with igf2 genotype influencing fat deposition in the pig (Nezer et al., 1999). In other studies, adipose tissue and isolated adipocytes have been shown to express IGF-II and other members of the IGF system in the pig (Hausman et al., 2002; Hausman et al., 2006; Gardan et al., 2006; 2008). Furthermore, we have found a higher IGF-II mRNA level in isolated intramuscular adipocytes than in subcutaneous or perirenal adipocytes in growing pigs (Gardan et al., 2006). Because intramuscular fat is the latest adipose tissue to develop in the pig (Lee and Kauffman, 1974; Hauser et al., 1997), we hypothesized that IGF-II gene expression may vary with the stage of development of the adipose cells. However, the expression pattern of IGF-II in relation with other components of the IGF system in differentiating adipose cells is still unknown. Therefore, the present study 
1 was undertaken to examine the expression of some genes of the IGF system in freshly isolated cells and during differentiation of stromal-vascular (s/v) cells in primary culture.

\section{Materials and methods}

\subsection{Animals and sample collection}

Studies were conducted in compliance with the French guidelines for care and use of animals in research. Male crossbred piglets (Pietrain x (Large White x Landrace)) were killed after an overnight fast by exsanguination after electrical stunning at 7 days of age $(2.6 \pm 0.3$ $\mathrm{kg}$ body weight, $\mathrm{n}=6$ ). Subcutaneous dorsal adipose tissue was aseptically removed immediately after death. Samples of $6 \mathrm{~g}$ were used for cell preparation.

\subsection{Cell isolation}

Cells were isolated by collagenase digestion as described by De Clercq et al. (1997). Briefly, subcutaneous adipose tissue was minced and digested in a HEPES phosphate buffer ( $2 \mathrm{~mL} / \mathrm{g}$ of tissue) containing $2 \% \mathrm{BSA}$ and $2 \mathrm{mg} / \mathrm{mL}$ collagenase II and XI ( $800 \mathrm{U} / \mathrm{mg}$; Sigma, St-Quentin Fallavier, France) in a shaking water bath for $45 \mathrm{~min}$ at $37^{\circ} \mathrm{C}$. Flask contents were filtered through nylon meshes $(200 \mu \mathrm{m})$. A five-fold excess of buffer containing no collagenase was added, before cells were centrifuged at $400 \mathrm{~g}$ for $10 \mathrm{~min}$ to separate floating adipocytes from the pellet of $\mathrm{s} / \mathrm{v}$ cells. Floating adipocytes were collected in DMEM at $37^{\circ} \mathrm{C}$, and then immediately processed for mRNA extraction. The pellet containing adipocyte progenitors is successively filtrated through a $100-\mu \mathrm{m}$ and $25-\mu \mathrm{m}$ nylon mesh. An aliquot $(20 \mu \mathrm{L})$ of cell suspension was stained with Trypan blue stain, and counted on a 
1 hemocytometer. A fraction of $\mathrm{s} / \mathrm{v}$ cells was then processed for mRNA extraction, whereas the

2 other fraction was cultured.

3

\subsection{Cell culture}

$\mathrm{S} / \mathrm{v}$ cells were seeded into 24 -well plates $\left(2 \mathrm{~cm}^{2} /\right.$ well $)$ at a density of $7.5 \times 10^{4}$ cells $/ \mathrm{cm}^{2}$ for morphological measurements, or in 6 -well plates at a similar density for gene expression analyses. Cells were maintained in a humidified $5 \% \mathrm{CO}_{2}$ atmosphere for $24 \mathrm{~h}$ at $37^{\circ} \mathrm{C}$. Plating medium consisted of Dulbecco's Modified Eagle's Medium (DMEM, Invitrogen, Cergy Pontoise, France) supplemented with 10\% fetal bovine serum (FBS), 100 $\mathrm{U} / \mathrm{mL}$ penicillin, $100 \mu \mathrm{g} / \mathrm{mL}$ streptomycin, $0.25 \mu \mathrm{g} / \mathrm{mL}$ fungizone, $0.25 \mu \mathrm{g} / \mathrm{mL}$ nystatine, 4 mM L-glutamine, $2.7 \mathrm{nM}$ insulin, $100 \mathrm{nM}$ cortisol. Cells were then cultured in a serum-free medium (DMEM/Ham's Nutrient Mixture F-12 (1:1) (Invitrogen), $100 \mathrm{U} / \mathrm{mL}$ penicillin, 100 $\mu \mathrm{g} / \mathrm{mL}$ streptomycin, $0.25 \mu \mathrm{g} / \mathrm{mL}$ fungizone, $0.25 \mu \mathrm{g} / \mathrm{mL}$ nystatine, $50 \mu \mathrm{mM} \quad \beta$ mercaptoethanol, $0.1 \mathrm{nM}$ ascorbic acid, $2.5 \mathrm{mM}$ L-glutamine, $10 \mu \mathrm{g} / \mathrm{ml}$ transferrin, $100 \mathrm{nM}$ cortisol, $0.2 \mathrm{nM}$ triiodothyronine). Media were supplemented with either insulin, and/or IGF-I or IGF-II (GroPep, Adelaïde, Australia, $10 \mathrm{nM}$ ). The media were then changed every other day. Cell differentiation was assessed by oil red-O and Hemalun Mayer staining (Gerfault et al., 1999). Cell diameters were also determined using a coulter counter (Coulter Multisizer, Beckmann) as previously described (Etherton, 1980). Cells with a diameter below $5 \mu \mathrm{m}$ were not considered.

\subsection{Malic enzyme assay}

Serum-free media were replaced with a $0.25 \mathrm{M}$ sucrose solution and cells were then collected. After sonication, homogenates were stored at $-70^{\circ} \mathrm{C}$ until use. Activity of malic enzyme (EC 1.1.1.40) was then measured (Hsu and Lardy, 1969). Substrate quantities were 
optimized $(100 \mu \mathrm{L})$ to ensure linearity of the reactions. Protein concentrations of homogenates were determined using the bicinchoninic acid assay with BSA as standard. Malic enzyme activity was expressed as nmoles NADPH produced/min/mg protein.

\subsection{Real-time RT-PCR}

Total RNA was extracted by the guanidium thiocyanate method (Chomczynski and Sacchi, 1987) with modifications for pig adipocytes (Louveau et al., 1991). Treated-DNAse total RNA $(2 \mu \mathrm{g})$ was reverse-transcribed using random hexamer primers and murine Moloney leukemia virus reverse transcriptase, according to the manufacturer's instructions. Primers were selected from porcine sequences as previously described (Gardan et al., 2006; Table 1). Real-time quantitative PCR analyses were performed in a final volume of $12.5 \mu \mathrm{L}$ starting with $5 \mathrm{ng}$ of reverse transcribed RNA and both sense and antisense primers $(500 \mathrm{nM}$ for each gene), using SYBR ${ }^{\circledR}$ Green I PCR core reagents in an ABI PRISM 7000 Sequence Detection System instrument (Applied Biosystems). Forty cycles of amplification were performed with each cycle consisting of denaturation at $95^{\circ} \mathrm{C}$ for $15 \mathrm{~s}$, and annealing and extension at $59^{\circ} \mathrm{C}$ for $1 \mathrm{~min}$. Cycle threshold $\left(\mathrm{C}_{\mathrm{T}}\right)$ values are means of triplicate measurements. Absence of contamination from either genomic DNA amplification or primer dimer formation was ensured using controls without reverse transcriptase or with no DNA template and no reverse transcriptase. A melting curve analysis was also performed, which resulted in single-product specific melting temperatures. Endogenous 18S ribosomal RNA amplifications were used for each sample to normalize the expression of the selected genes. A pool of adipocyte cDNA was used as an inter-plate calibrator for each gene. As PCR efficiencies for selected genes and $18 \mathrm{~S}$ gene were close to 1 , the relative quantification for a target gene in comparison to $18 \mathrm{~S}$ in a given sample in reference to the calibrator, was calculated according to the following formula (Pfaffl, 2001): 


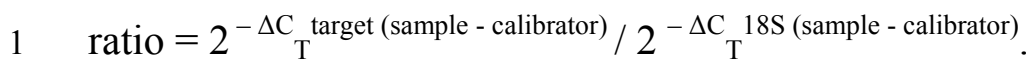

2

\subsection{Statistical analyses}

Data were processed by analysis of variance using the General Linear Model procedure of SAS (SAS Inst., Inc., Cary, NC, USA). Differences were considered to be significant at $\mathrm{P}<0.05$. The mean separation procedure used was a multiple $\mathrm{T}$-test comparison. All data are presented as the mean + S.E.M. from at least three independent experiments.

\section{Results}

\subsection{Differentiation of $s / v$ cells into mature adipocytes}

Cells became confluent at approximately day 4 of culture. During the following days, cells acquired a round shape and numerous lipid droplets of variable size filled up cytoplasm (Fig. 1). On day 9 of culture, most of the cells were completely filled with multiple lipid droplets. In addition, mean cell diameter continuously increased during the process of differentiation (Fig. 1). The gene expressions of PPAR $\gamma$, malic enzyme and insulin receptor, markers of adipose differentiation, were assessed (Fig. 2). These parameters increased during differentiation even though the difference between D3 and D6 of culture was not significant. A significant activity of malic enzyme, a later marker enzyme of adipose differentiation, was also detected from day 6 onwards (Fig. 3). The comparison of freshly isolated cells further supports in vitro data with higher PPAR $\gamma(\mathrm{P}<0.05)$ and malic enzyme $(\mathrm{P}<0.1)$ mRNA levels in adipocytes than in $\mathrm{s} / \mathrm{v}$ cells.

\subsection{Effects of IGF-I and IGF-II on the differentiation of $s / v$ cells}


The addition of IGF-I or IGF-II to the insulin-supplemented medium did not markedly affect malic enzyme activity at day 6 and day 9 of culture (Fig. 3). On the opposite, when IGF-I or IGF-II were added in media in the absence of insulin, malic enzyme activity was much lower $(\mathrm{P}<0.05)$ than the same activity measured in insulin-supplemented medium with or without IGFs at each time of culture.

\subsection{Gene expressions of the IGF system in freshly isolated cells and in cultured cells}

Expressions of genes related to the IGF family were determined in freshly isolated adipocytes and in s/v cells (D0), and in 3- and 6-day-cultured s/v cells (Fig. 4). Different gene expression patterns can be identified. Levels of IGF-I and IGFBP-3 mRNA were higher $(\mathrm{P}<$ 0.05) in adipocytes than in $\mathrm{s} / \mathrm{v}$ cells at D0. During cell culture, both IGF-I and IGFBP-3 mRNA levels increased but the increase was significant $(\mathrm{P}<0.05)$ only for IGF-I. In contrast, levels of IGF-II and IGFBP-5 mRNA were lower $(\mathrm{P}<0.05)$ in adipocytes than in s/v cells at D0. During cell culture, both IGF-II and IGFBP-5 mRNA levels declined but the decrease was significant $(\mathrm{P}<0.05)$ only for IGF-II. Expression pattern for IGF-IR, IGF-IIR and IGFBP-2 genes were similar with lower mRNA levels in adipocytes than in s/v cells at D0. For IGFBP-4 gene expression, there was neither significant difference between freshly isolated cells nor between cultured cells.

\section{Discussion}

Expressions of some genes of the IGF system were evaluated in both freshly isolated adipose cells and cultured s/v cells to increase common knowledge on this system with respect to adipose tissue development. Indeed, the possible role of IGF-II on adipocyte differentiation has been poorly investigated in the literature, despite an increasing evidence for a role of this factor on body fat deposition in pigs. The present study clearly shows that 
1 IGF-I, IGF-II, IGF receptor, IGFBP-2, -3, -4 and -5 genes were expressed in freshly isolated

$2 \mathrm{~s} / \mathrm{v}$ cells, differentiating adipose cells, and lipid-filled adipocytes. The expression patterns

during differentiation differed between the genes examined, with IGF-I and IGFBP-3 genes exhibiting clearly an increased expression and both IGF-II and IGFBP-5 showing a clear decreased expression during culture. The comparisons of gene expressions in freshly isolated $\mathrm{s} / \mathrm{v}$ cells with that in adipocytes further support these observations.

The presence of IGF-I mRNA in preadipocytes and/or adipocytes is consistent with previous findings in pigs (Gaskins et al., 1990), rats (Peter et al., 1993) and humans (Wabitsch et al., 2000). The detection of IGF-II, IGFBP-2,-3 and -5 mRNA in the current study agrees with data obtained in neonatal pig adipose tissue and fetal s/v cells using gene microarrays (Hausman et al., 2006). In contrast, Boney et al (1994) failed to detect IGF-II mRNA by Northern blot analysis in primary culture of mouse preadipocytes as well as in 3T3-L1 preadipocyte cells. Even though one cannot exclude the lack of sensitivity of Northern blot analysis, these findings reflect likely the difference between rodents and other mammals. Expressed genes in the current study are very likely secreted, because analyses of conditioned media from cultured porcine $\mathrm{s} / \mathrm{v}$ cells also lead to the identification of IGF-I, IGF-II and several IGFBPs (Gaskins et al., 1990; Chen et al., 1996; Hausman et al., 2006). Likewise, human preadipocytes and adipocytes have been shown to secrete IGF-I, IGF-II and at least IGFBP-3 (Wabitsch et al., 2000). In the current study, both IGF-I and IGF-II receptor gene expressions were also identified in porcine adipocytes, freshly isolated $\mathrm{s} / \mathrm{v}$ cells and cultured cells. The presence of IGF-I receptor mRNA in pre-adipocytes concurs with previous findings in pigs (Richardson et al., 1994; Gerfault et al., 1999) and rabbit (Nougues et al., 1993). The expression of IGF-I and IGF-II receptors in mature adipocytes has been examined less extensively, and available data from the literature are sometimes controversial. Even though Richardson et al. (1994) failed to detect IGF-I receptors on porcine fat cells using in situ 
1 binding, we have previously shown the presence of IGF-I receptor mRNA in adipocytes

2 (Gerfault et al., 1999; Gardan et al., 2006), and IGF-I binding sites in adipose tissue

membranes (Louveau and Le Dividich, 2002). In human adipocytes, the presence of IGF-I receptors has been also demonstrated (Kern et al., 1989). It is also possible that adipocytes express insulin receptor/IGF-I receptor hybrids as described in rabbit fat (Bailyes et al., 1997).

The current study provides novel information on the expression patterns of genes of the IGF system during porcine adipose cell differentiation. Whereas IGF-I and IGFBP-3 exhibited an increased expression, a second group of genes involving IGF-II and IGFBP-5 had a decreased expression during differentiation. The finding of an increase in both IGF-I and IGFBP-3 mRNA levels during differentiation agrees with data reported in human (Wabitsch et al., 2000). This supports a significant role of IGF-I in adipocyte differentiation as described in cells in primary culture as well as in different adipose cell lines (Wabitsch, 1995; Grégoire et al., 1998; Louveau and Gondret, 2006; Rosen and MacDougald, 2006). The finding that both IGF-I and insulin receptors exhibited a similar pattern of expression did not allow us to distinguish the action of IGF-I from that of insulin. Because IGF-I and insulin did not have the same ability to increase malic enzyme activity in cells after 6 days of culture, we suggest that IGF-I may exert its action through insulin receptors. An action through insulin/IGF-I hybrid receptors is also possible.

With respect to the expression pattern of IGF-II and IGFBP-5 genes, much less is known on adipose cells. In the literature, the number of genes that have been shown to be down-regulated during adipose conversion is quite low compared with the number of upregulated genes (Fève, 2005). It remains to be investigated whether high expression of IGF-II and IGFBP-5 genes in $\mathrm{s} / \mathrm{v}$ cells at the beginning of cell culture may contribute to the maintenance of the preadipose state, or could delay the differentiation process. IGFBP-5 has been previously described to inhibit IGF actions, to potentiate IGF actions, or to have 
1 independent IGF effects (Beattie et al., 2006). Interestingly, a parallel decrease in IGF-II and

2 IGFBP-5 mRNA levels has been also described during differentiation of porcine embryonic myogenic cells (Xi et al., 2007). In addition, IGFBP-5 has been shown to block differentiation

4

5

6

7 inhibit cell differentiation and to reduce adipose tissue development in non rodent models. 


\section{Acknowledgements}

The authors thank C. Tréfeu for her expert technical assistance and O. Sarr for IGFBP primer designs. The authors are also very grateful to F. Gondret for helpful discussion and critical review of the manuscript.

\section{Grants}

D. Gardan was supported by a grant from the French Ministry of Education and Research.

\section{References}

Bailyes, E.M., Navé, B.T., Soos, M.A., Orr, S.R., Hayward, A.C., Siddle, K., 1997. Insulin receptor/IGF-I receptor hybrids are widely distributed in mammalian tissues: quantification of individual receptor species by selective immunoprecipitation and immunoblotting. Biochem. J. 327, 209-215.

Beattie, J., Allan, G.J., Lochrie, J.D., Flint, D., 2006. Insulin-like growth factor binding protein-5 (IGFBP-5): a critical member of the IGF axis. Biochem. J. 395: 1-19.

Boney, C.M., Moats-Staats, B.M., Stiles, A.D., D’Ercole, A.J., 1994. Expression of insulinlike growth factor-I (IGF-I) and IGF-binding proteins during adipogenesis. Endocrinology 135, 1863-1868.

Chao, W., D'Amore, P., 2008. IGF2: Epigenetic regulation and role in development and disease. Cytokine Growth Factor Rev 19, 111-120.

Chen, N.X., Hausman, G.J., Wright, J.T., 1995. Influence of age and fetal hypophysectomy on porcine preadipocytes: insulin-like growth factor-I (IGF-I) response, receptor binding and IGF binding proteins secretion. Growth Dev. Aging 59, 193-206. 
1 Chomczynski, P., Sacchi, N., 1987. Single-step method of RNA isolation by acid guanidinium thiocyanate-phenol-chloroform extraction. Anal. Biochem. 162, 156-159.

Constância, M., Hemberger, M., Hughes, J., Dean, W., Ferguson-Smith, A., Fundele, R., Stewart, F., Kelsey, G., Fowden, A., Sibley, C., Reik, W., 2002. Placental-specific IGF-II is a major modulator of placental and fetal growth. Nature 417, 945-948.

De Clercq, L., Mourot, J., Genart, C., Davidts, V., Boone, C., Remacle, C., 1997. An antiadipocyte monoclonal antibody is cytotoxic to porcine preadipocytes in vitro and depresses the development of pig adipose tissue. J. Anim. Sci. 75, 1791-1797.

Etherton, T.D., 1980. Subcutaneous adipose tissue cellularity of swine with different propensities for adipose tissue growth. Growth 44, 192-191.

Fève, B., 2005. Adipogenesis: cellular and molecular aspects. Best Pract. Res. Clin. Endocrinol. Metab. 19, 483-499.

Firth, S.M., Baxter, R.C., 2002. Cellular actions of the insulin-like growth factor binding proteins. Endocr. Rev. 23, 824-854.

Fowden, A.L., 2003. The insulin-like growth factors and feto-placental growth. Placenta 24, 803-812.

Gardan, D., Gondret, F., Louveau,I., 2006. Lipid metabolism and secretory function of porcine intramuscular adipocytes compared with subcutaneous and perirenal adipocytes. Am. J. Physiol. Endocrinol. Metab. 291, E372-E380.

Gardan, D., Gondret, F., Van den Maagdenberg, K., Buys, N., De Smet, S., Louveau, I., 2008. Lipid metabolism and cellular features of skeletal muscle and subcutaneous adipose tissue in pigs differing in IGF-II genotype. Domest. Anim. Endocrinol. 34, 45-53.

Gaskins, H.R., Kim, J.W., Wright, J.T., Rund, L.A., Hausman, G.J., 1990. Regulation of insulin-like growth factor-I ribonucleic acid expression, polypeptide secretion, and 
binding protein activity by growth hormone in porcine preadipocyte cultures. Endocrinology 126, 622-630.

Gerfault, V., Louveau, I., Mourot, J., 1999. The effect of GH and IGF-I on preadipocytes from Large White and Meishan pigs in primary culture. Gen. Comp. Endocrinol. 114 : 396-404.

Grégoire, F.M., Smas, C.M., Sul, H.S., 1998. Understanding adipocyte differentiation. Physiol. Rev. 78, 783-809.

Hauser, N., Mourot, J., De Clercq, L., Genart, C., Remacle, C., 1997. The cellularity of developing adipose tissues in Pietrain and Meishan pigs. Reprod. Nutr. Dev. 37, 617-625.

Hausman, G.J., Poulos, S.P., Richardson, R.L., Barb, C.R., Andacht, T., Kirk, H.C., Mynatt, R.L., 2006. Secreted proteins and genes in fetal and neonatal pig adipose tissue and stromal-vascular cells. J. Anim. Sci. 84, 1666-1681.

Hausman, G.J., Richardson, R.L., Simmen, F.A., 2002. Secretion of insulin-like growth factor (IGF)-I and -II and IGF binding proteins (IGFBPs) in fetal stromal-vascular (S-V) cell cultures obtained before and after the onset of adipogenesis in vivo. Growth Dev. Aging $66,11-26$.

Hausman, G.J., 1989. The influence of insulin, triiodothyronine (T3) and insulin-like growth factor I (IGF-I) on the differentiation of preadipocytes in serum-free cultures of pig stromal-vascular cells. J. Anim. Sci. 67, 3136-3143.

Hsu, R.Y., Lardy, H.A. 1969. Malic enzyme. Methods in Enzymology 17, 230-235.

Jones, J.I., Clemmons, D.R., 1995. Insulin-like growth factors and their binding proteins: biological actions. Endocr. Rev. 16, 3-34.

Kern, P.A., Svoboda, M.E., Eckel, R.H., Van Wyk, J.J., 1989. Insulin-like growth factor action and production in adipocytes and endothelial cells from human adipose tissue. Diabetes 38, 710-717. 
1 Lee, Y.B., Kauffman, R.G., 1974. Cellular and enzymatic changes with animal growth in porcine intramuscular adipose tissue. J. Anim. Sci. 38, 532-537.

Louveau, I., Chaudhuri, S., Etherton, T.D., 1991. An improved method for isolating RNA from porcine adipose tissue. Anal. Biochem. 196, 308-310.

Louveau, I., Le Dividich, J., 2002. GH and IGF-I binding in adipose tissue, liver and skeletal muscle in response to milk intake level in piglets. Gen. Comp. Endocrinol. 126, 310-317.

Louveau, I., Gondret F., 2004. GH and insulin affect fatty acid synthase activity in isolated porcine adipocytes in culture without any modifications of sterol regulatory element binding protein-1 expression. J. Endocrinol. 81, 271-280.

Mukherjee, A., Wilson, E.M., Rotwein, P., 2008. IGF binding protein-5 blocks skeletal muscle differentiation by inhibiting IGF actions. Mol. Endocrinol. 22, 206-215.

Nezer, C., Moreau, L., Brouwers, B., Coppieters, W., Detilleux, J., Hanset, R., Karim, L., Kvasz, A., Leroy, P., Georges, M., 1999. An imprinted QTL with major effect on muscle mass and fat deposition maps to the IGF2 locus in pigs. Nat. Genet. 21, 155-156.

Nougues, J., Reyne, Y., Chery, T., Garandel, V., Sobriano, J., 1993. Differentiation of adipocyte precursors in a serum-free medium is influenced by glucocorticoids and endogenously produced insulin-like growth factor-I. Int. J. Obesity 17, 159-167.

O'Dell, S.D., Day, I.N., 1998. Insulin-like growth factor II (IGF-II). Int. J. Biochem. Cell Biol. 30, 767-771.

Peter, M.A., Winterhalter, K.H., Böni-Schnetzler, M., Froesch, E.R., Zapf, J., 1993. Regulation of insulin-like growth factor-I (IGF-I) and IGF-binding proteins by growth hormone in rat white adipose tissue. Endocrinology 133 , 2624-2631.

Pfaffl, M.W., 2001. A new mathematical model for relative quantification in real-time RTPCR. Nucleic Acids Res. 29, 2002-2007. 
1 Richardson, R.L., Hausman, G.J., Wright, J.T., 1994. In situ binding and

2 immunocytochemistry of insulin-like growth factor-I receptors in primary cultures of

3 porcine adipose tissue stromal vascular cells treated with indomethacin. J. Anim. Sci. 72,

$4 \quad 969-975$.

5 Rosen, E.D., MacDougald, O.A., 2006. Adipocyte differentiation from the inside out. Nat.

$6 \quad$ Rev. Mol. Cell. Biol. 7, 885-896.

7 Wabitsch, M., Hauner, H., Heinze, E., Teller, W.M., 1995. The role of growth

8 hormone/insulin-like growth factors in adipocyte differentiation. Metabolism 44 (Suppl 4),

$9 \quad 45-49$.

Wabitsch, M., Heinze, E., Debatin, K.M., Blum, W.F., 2000. IGF-I and IGFBP-3 expression in cultured human preadipocytes and adipocytes. Horm. Metab. Res. 32, 555-559.

Xi, G., Hathaway, M.R., Dayton, W.R., White, M.E., 2007. Growth factor messenger ribonucleic acid expression during differentiation of porcine embryonic myogenic cells. J. Anim. Sci. 85, 143-150. 


\section{Figure legends}

Fig. 1. Adipose cells during differentiation in primary culture. Cells were first cultured in a plating medium and were then cultured from day 1 to day 9 in a defined medium supplemented with insulin (10 nM). (A) Photomicrographs of cultured stromal-vascular (s/v) cells at D3 and D6 of culture (original magnification x200). (B) Mean diameters $(\mu \mathrm{m})$ were measured at D0, D3, D6 and D9 as described in Materials and methods. Data represent means \pm S.E.M. of experiments performed in duplicate $(n=4)$.

Fig. 2. Transcript levels of markers of adipose cell differentiation in freshly isolated cells and in stromal-vascular $(\mathrm{s} / \mathrm{v})$ cells in primary culture. Adipocytes and $\mathrm{s} / \mathrm{v}$ cells were collected on the day of slaughtering (D0). S/v cells were cultured in a defined medium supplemented with insulin (10 nM) and collected on day 3 (D3) and day 6 (D6) of culture for mRNA extraction. Levels of mRNA were quantified by real-time PCR as described in Materials and methods. Values are means \pm SEM $(n=6$ for adipocytes (Ad-D0) and $s / v$ cells $(S / v-D 0) ; n=3$ for $s / v$ cells in culture (S/v-D3 and S/v-D6). Within a group of cells (freshly isolated vs culture), values differed at $* \mathrm{P}<0.05, \uparrow \mathrm{P}<0.1$.

Fig. 3. Malic enzyme activity in stromal-vascular $(\mathrm{s} / \mathrm{v})$ cells in primary culture. Cells were cultured from day 1 to day 9 in a defined medium supplemented with insulin (ins) and/or IGFI or IGF-II (10 nM). Malic enzyme activity was measured on D6 and D9 of culture as described in Materials and methods and expressed as nmol NADPH per mg proteins. Values are means \pm S.E.M. of experiments performed in triplicate $(n=4)$. Means with different superscript letters are different $(\mathrm{P}<0.05)$. 
1 Fig. 4. Transcript levels of IGF-I, IGF-II, IGFBPs and IGF receptors in freshly isolated cells

2 and in stromal-vascular $(\mathrm{s} / \mathrm{v})$ in primary culture. Adipocytes and $\mathrm{s} / \mathrm{v}$ cells were collected on 3 the day of slaughtering (D0). S/v cells were cultured in a defined medium supplemented with 4 insulin (10 nM) and collected on day 3 (D3) and day 6 (D6) of differentiation for mRNA 5 extraction. Levels of mRNA were quantified by real-time PCR as described in Materials and 6 methods. Values are means $\pm \operatorname{SEM}(\mathrm{n}=6$ for adipocytes $($ Ad-D0) and $\mathrm{s} / \mathrm{v}$ cells $(\mathrm{S} / \mathrm{v}-\mathrm{D} 0) ; \mathrm{n}=$

73 for s/v cells in culture (S/v-D3 and S/v-D6). Within a group of cells (freshly isolated vs 8 culture), values differed at $* \mathrm{P}<0.05, \uparrow \mathrm{P}<0.1$.

9 
1 Table 1. Primers used for analysis of gene expression by real-time RT-PCR.

\begin{tabular}{|c|c|c|c|}
\hline Gene $^{1}$ & $\begin{array}{l}\text { Accession } \\
\text { number }\end{array}$ & Forward primer $\left(5^{\prime} \rightarrow 3^{\prime}\right)$ & Reverse primer $\left(5^{\prime} \rightarrow 3^{\prime}\right)$ \\
\hline IGF-I & M31175 & GCTGGACCTGAGACCCTCTGT & TACCCTGTGGGCTTGTTGAAAT \\
\hline IGF-II & X56094 & AGGGCATCCAAACCACAAAC & GGGTTCAATTTTTGGTATGTAACTTG \\
\hline IGFBP-2 & AF120326 & GCACCTGTACTCCTTGCACATC & CGCTGCCCATTCAGAGACAT \\
\hline IGFBP-3 & AF085482 & CATCCCCAACTGCGACAAG & ATCCACGCACCAGCAGAAG \\
\hline IGFBP-4 & BX921877 & ATCGAGGCCATCCAGGAAA & CCCCGATGACCTTCATCTTG \\
\hline IGFBP-5 & NM_214099. & CGTGGACAAGTACGGGATGA & CGAAGCTGTGGCACTGGAA \\
\hline IGF-I R & U58370 & CAACCTCCGGCCTTTTACTTT & CAGGAATGTCATCTGCTCCTTCT \\
\hline IGF-II R & CB469268 & TGCCCGGTGAAGAGCAA & TTGTCCCCACACACGATAATGT \\
\hline Insulin R & AF102858 & CAGCGATGTATTTCCATGTTCTGT & GCGTTTCCCTCGTACACCAT \\
\hline ME & X93016 & TGGTGACTGATGGAGAACGTATTC & CAGGATGACAGGCAGACATTCTT \\
\hline $\operatorname{PPAR} \gamma$ & AF103946 & ATTCCCGAGAGCTGATCCAA & TGGAACCCCGAGGCTTTAT \\
\hline
\end{tabular}

2

$3{ }^{1}$ IGF-I and IGF-II, insulin-like growth factor-I and -II; IGFBP, insulin-like growth

4 factor binding protein; R, receptor; ME, malic enzyme; PPAR- $\gamma$, peroxisome proliferator-

5 activated receptor gamma.

6 
Gardan et al.

Fig. 1
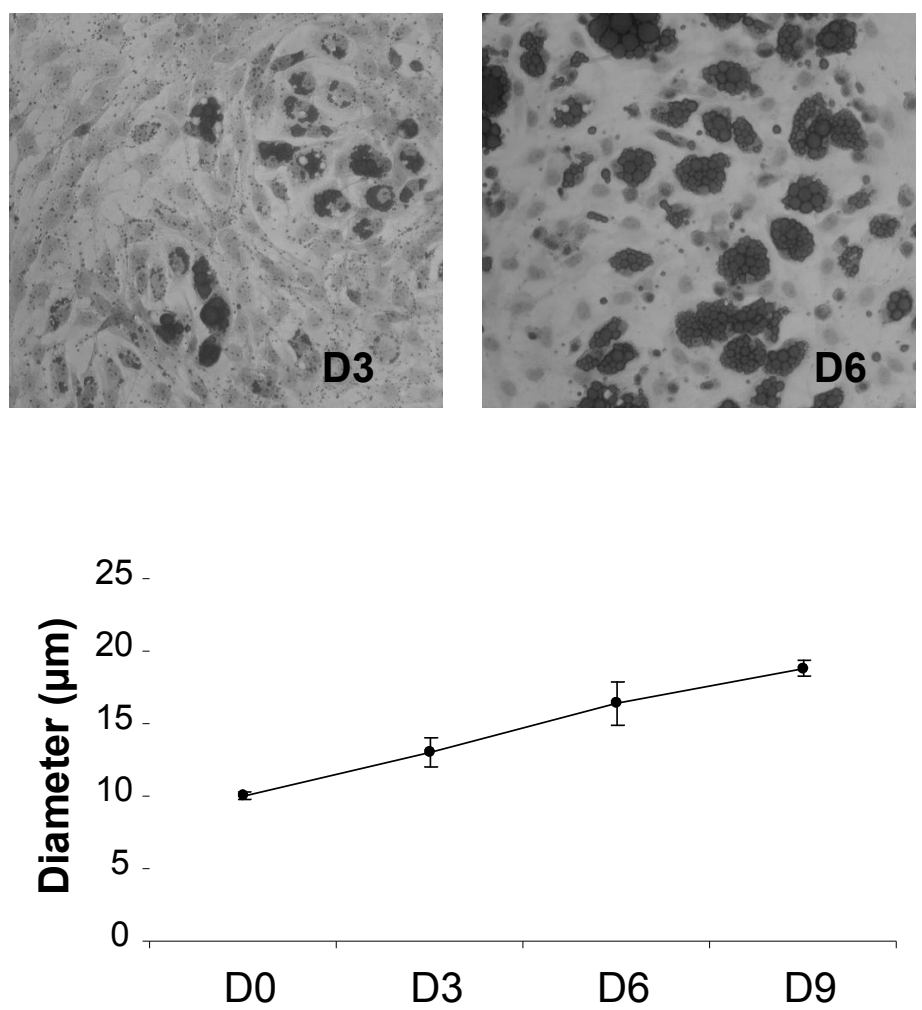
Gardan et al.

Fig. 2
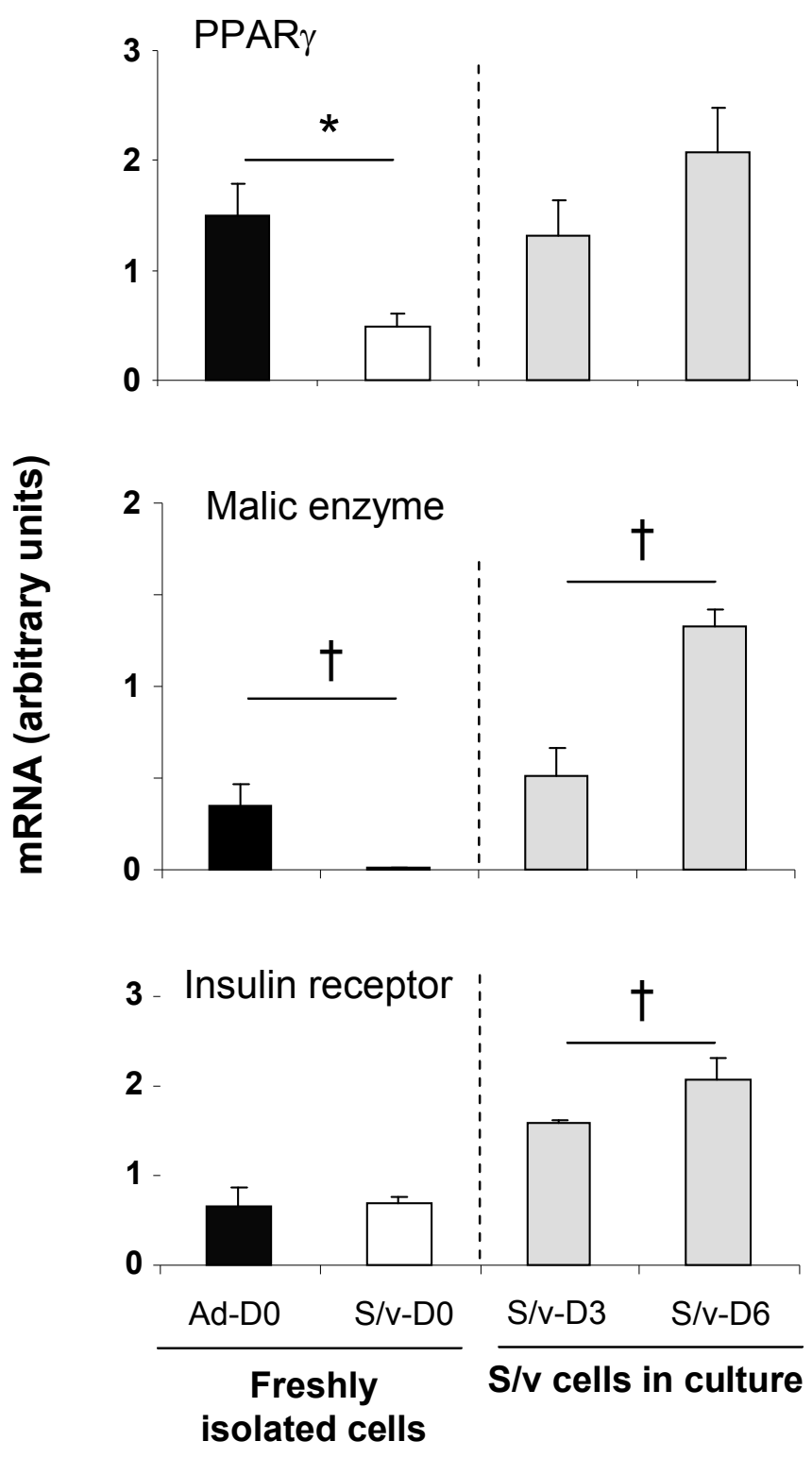
Gardan et al.

Fig. 3

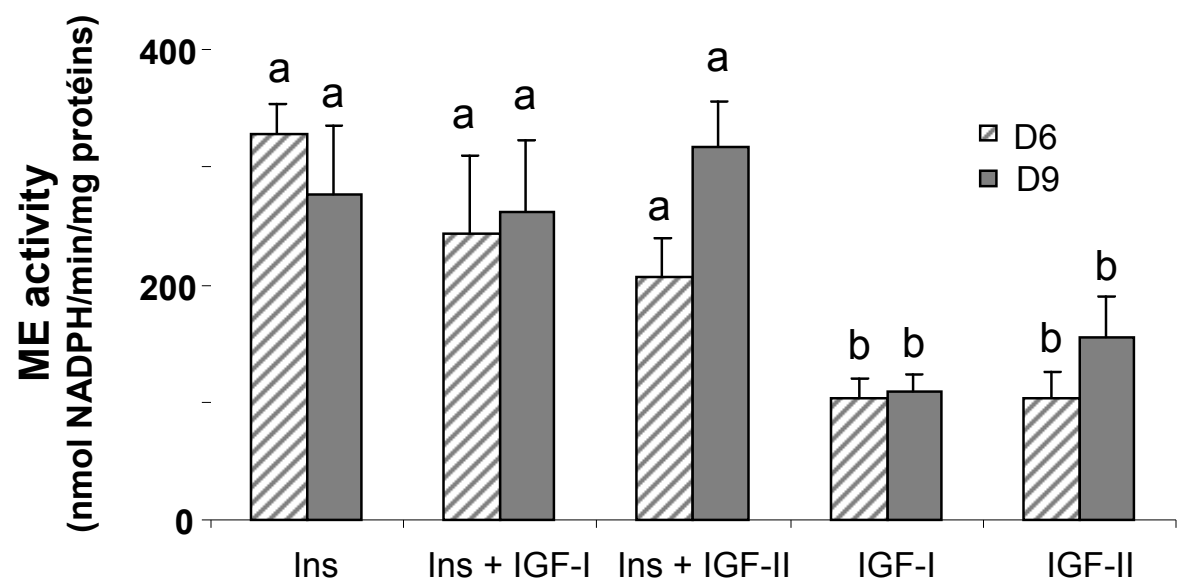


Gardan et al.

Fig. 4
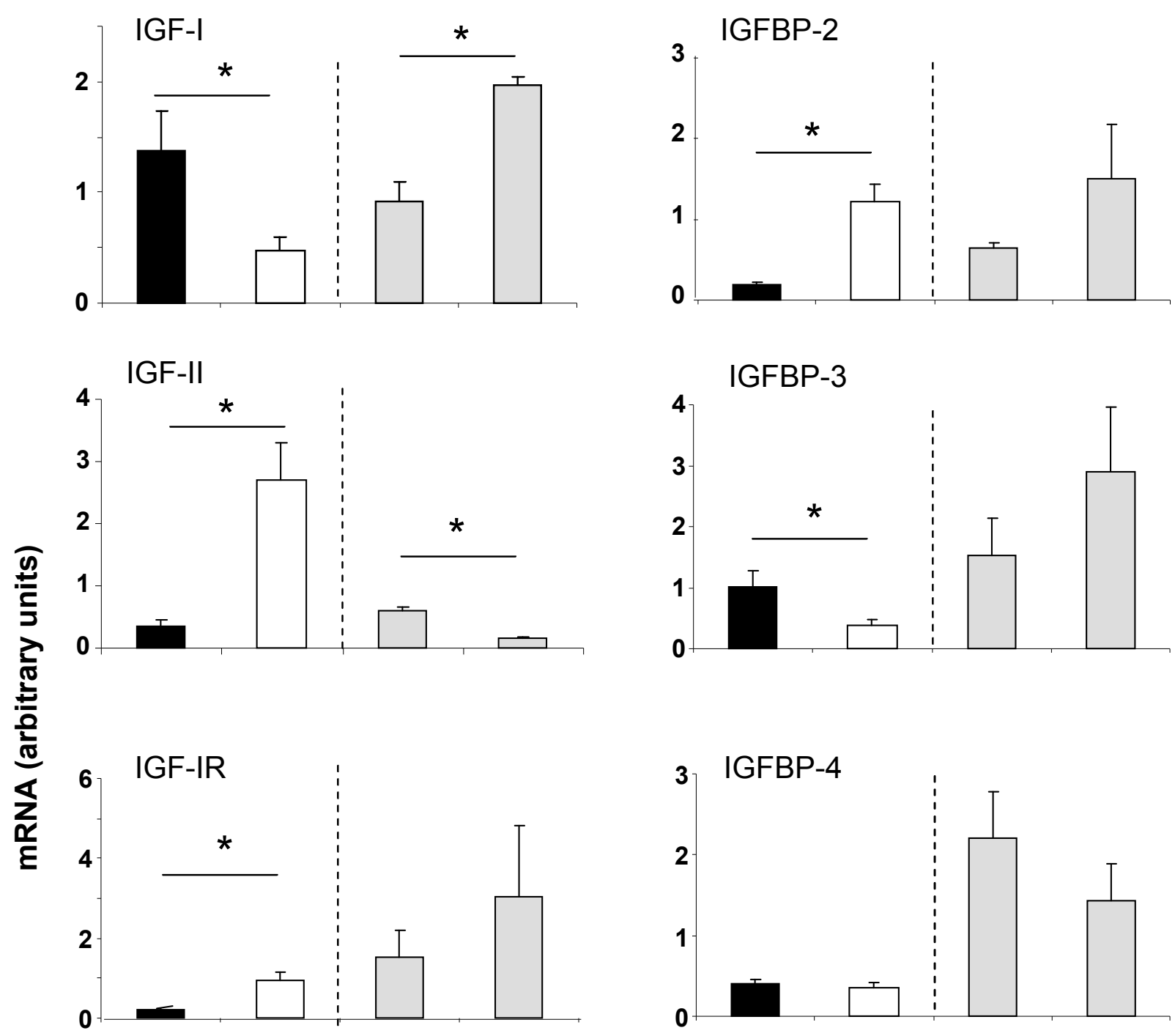

IGFBP-3

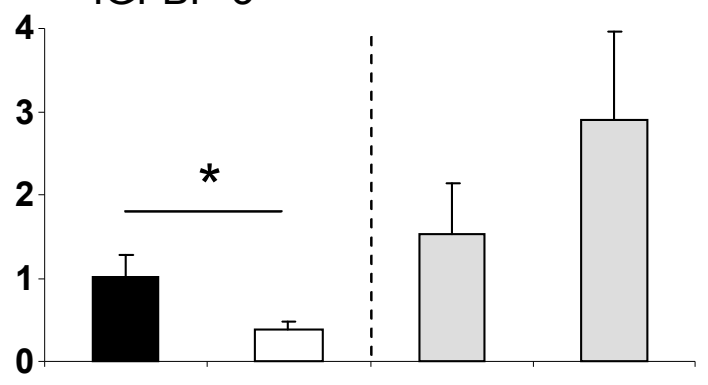

IGF-IIR
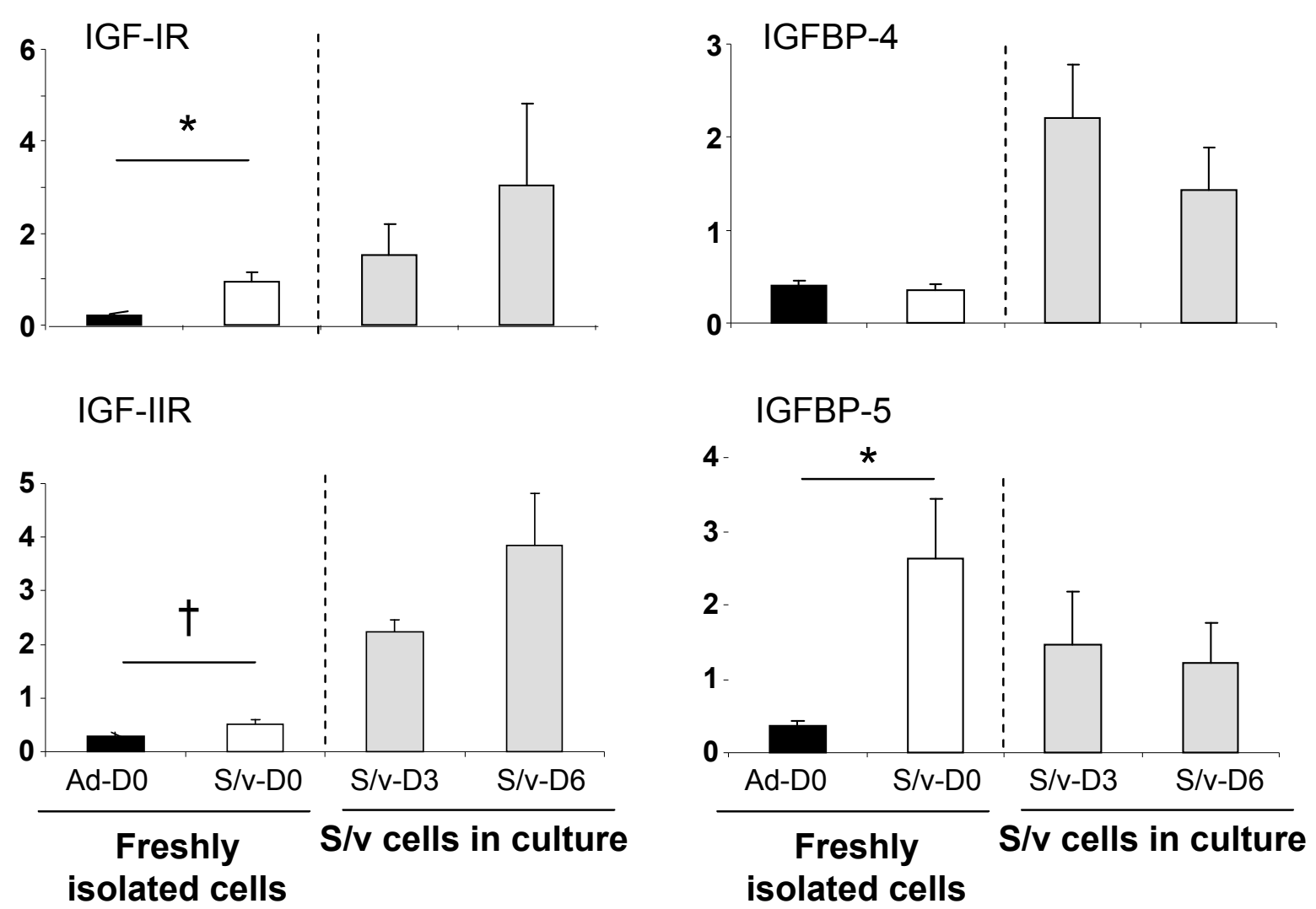